\title{
Morality-in-interaction: Toddlers' recyclings of institutional discourses of feeling during peer disputes in daycare
}

DOI:

10.1515/text-2020-2081

\section{Document Version}

Accepted author manuscript

Link to publication record in Manchester Research Explorer

\section{Citation for published version (APA):}

Kyratzis, A., \& Köymen, B. (2020). Morality-in-interaction: Toddlers' recyclings of institutional discourses of feeling during peer disputes in daycare. Text and Talk, 40(5), 623-642. https://doi.org/10.1515/text-2020-2081

\section{Published in:}

Text and Talk

\section{Citing this paper}

Please note that where the full-text provided on Manchester Research Explorer is the Author Accepted Manuscript or Proof version this may differ from the final Published version. If citing, it is advised that you check and use the publisher's definitive version.

\section{General rights}

Copyright and moral rights for the publications made accessible in the Research Explorer are retained by the authors and/or other copyright owners and it is a condition of accessing publications that users recognise and abide by the legal requirements associated with these rights.

\section{Takedown policy}

If you believe that this document breaches copyright please refer to the University of Manchester's Takedown Procedures [http://man.ac.uk/04Y6Bo] or contact uml.scholarlycommunications@manchester.ac.uk providing relevant details, so we can investigate your claim.

\section{OPEN ACCESS}


Morality-in-interaction: Toddlers' recyclings of institutional discourses of feeling during peer disputes in daycare

Article in press in Text \& Talk

Amy Kyratzis ${ }^{1} \&$ Bahar Köymen ${ }^{2}$

${ }^{1}$ University of California, Santa Barbara, USA

${ }^{2}$ University of Manchester, UK 


\begin{abstract}
Everyday discursive practices comprising "emotion talk" constitute a site where morality is socialized. Yet few studies have examined how emotional expressions are assembled and serve as integral parts of the unfolding action in multi-party, remedial interchanges involving caregivers and children in early care settings. This paper examines a particular type of emotion talk, complement constructions with verbs of feeling ("want") and saying (e.g., "Are you saying 'no don't stand on me'?) primed by caregivers as part of a curriculum encouraging children to use their words to express their feelings so children become sensitized to one another's hurt feeling during peer disputes. The data were drawn from a larger corpus of video recordings of children's naturalistic interaction collected over two years in two toddler-infant daycare centers with children aged $12-30$ months. A talk-in-interaction approach was adopted. The syntactic formats provided to children by caregivers, and how children and caregivers recycled and laminated utterances with different kinds of modalities over turns, uncovered usually unarticulated normative socio-cultural assumptions regarding the shaping of affect at the daycare. The results illustrate how affective work in remedial interchanges provides a resource for participants to articulate moral values and underscore children's agency.
\end{abstract}

Keywords: morality-in-interaction, emotion talk, children's peer interactions, language socialization, remedial interchanges 


\section{Introduction}

Everyday discursive practices comprising "emotion talk", or talk about emotions, constitute a site where notions of morality are socialized (Cekaite 2013; Ochs and Schieffelin 1989). Moreover, recent work, rather than taking an internal cognitive view of emotion, has focused on emotion-in-interaction, that is, how emotional expressions serve as integral parts of the "environment of unfolding action being constituted" in a social encounter, particularly how they index appropriate and inappropriate behavior and influence the participation structure among participants (Goodwin, Cekaite and Goodwin 2012: 21). Yet little research has addressed how emotion talk unfolds in multi-party interactions involving adult caregivers and children in educational settings, which have been less studied than familial settings (Cekaite 2013).

In this paper, we examine the role of emotion talk primed by caregivers and taken up by toddlers in sequences of conflict interaction in shaping the local moral order in two California daycare centers. In particular, we focus on situations in which a child is a victim of a peer's untoward action, and a caregiver intervenes by priming institutionally sanctioned emotion talk encouraging the child to "use your words". According to the curriculum implemented, called RIE (Resources for Infant Educarers, see section 3), the affective statements (e.g. "Are you saying 'no, don't stand on me?"') are intended to provide moral insight to the peer about the hurt feeling experienced by that transgressed-upon child. The impetus of the affective statements is toward peer-to-peer understanding and restoration of the social order. As discussed by Goffman (1971: 192), remedial work often gives rise to "recycling". In keeping with the special issue theme, we ask the following questions. First, how are the affective expressions shaped syntactically by the caregivers so as to frame the peer's action as in need of being remedied? Second, how are the affective expressions recycled by both the child and the caregiver over 
sequences of turns, with what forms of embodiment? Third, how do these expressions take part in evolving courses of action and alignment displays, and how do they "make relevant specific moral interpretive frameworks" (Cekaite and Evaldsson this issue) at the daycare centers?

In the following section, we describe prior literature on emotion talk, children's peer interactions, and morality- and emotion-in-interaction. In the sections that follow, we present the methods and analysis of the study and then discuss results in terms of what they indicate about the moral work accomplished through exhibitions of affect in U.S. daycare settings.

\section{Literature Review}

\subsection{Language Socialization and Emotion Talk}

Everyday discursive practices comprising "emotion talk" constitute a site where local values as well as "notions of morality and personhood are inscribed, providing a link to broader societal ideologies" (Cekaite 2013; 512; see also Ochs and Schieffelin 2009, 2011, Clancy 1996; Kyratzis 2001). Caregivers' expressions of concern, disturbance, love, joy, annoyance, displeasure, or admonishment can provide children with moral insight to help them recognize the consequences of actions for their own and others' feelings (Clancy 1996; Cook-Gumperz and Kyratzis 2001).

Recent attention has shifted away from a focus uniquely on families to how adults socialize children in educational settings (Burdelski 2010; Cekaite and Holm 2017). For example, when they are invited to share reports of events that had recently occurred during recess time ("recess talk"), children at a Swedish preschool could be steered by their teachers through admonishments and verbal framing to view negative emotions (anger) as either "normatively and morally valid and rational or ... as unreasonable, self-indulgent, and morally condemnable” 
(Cekaite 2013: 520).

Recent research has also demonstrated how children socialize one another in various contexts such as schools, neighborhoods, etc. without the involvement of adults (M.H. Goodwin and Kyratzis 2011, 2014). Middle-class preschool boys telling narratives of pretense, for example, may learn from one another that "scary" monsters should be embraced while being "scared" is less appropriate, or that it is okay to exhibit caring, loving stances under certain circumstances, such as when a particular group member is not present (Kyratzis 2001). Children do not merely appropriate adults' rules but exert agency in interpreting school rules and norms, orienting to them in ways that help them position one another in particular ways in the local social order, one which may sometimes involve nearby adults as well as peers (Martin and Evaldsson 2012; Cekaite 2003; Cekaite and Evaldsson 2008; Kemp and Kyratzis 2018; Kidwell 2005; Kyratzis 2017; Johnson 2017; Tarım and Kyratzis 2012). In these ways, adult-child socialization may be viewed as a bi-directional, multi-party interactional process.

\subsection{Emotion and Morality-in-Interaction}

Rather than taking an internal cognitive view of morality, recent approaches examine how morality is enacted in interaction through practices such as blaming, accusations, accounts, and assessments, all of which index breaches in the moral order (Cekaite and Evaldsson this issue; Evaldsson and Svahn 2014; Goffman 1971). Recent work has also focused on how emotional expressions can serve as actions that are integral parts of the "environment of unfolding action being constituted" in a social encounter, as participants orient to "the bodies and actions of others" (Goodwin, Cekaite and Goodwin 2012: 21; M.H. Goodwin 2007).

Affect, for example, plays a major role in assessment activity, a way in which children in 
their peer groups articulate group norms (M.H. Goodwin 2007). Affect can be used to underscore an assessment about a target, thereby influencing the "participation", specifically, the "forms of involvement" exhibited by participants of the encounter towards their talk and one another (Goodwin and Goodwin 2004; Goffman 1981). By making their emotional "stance" towards the target of an assessment publicly visible, a participant is provided with a resource to exhibit particular kinds of alignment with other participants present in an interaction and "build their local social relations" with them (M.H. Goodwin 2007: 354; Goodwin et al. 2012; Evaldsson and Svahn 2012). For example, Goodwin, Cekaite, and Goodwin (2012) describe how one of the girls present during lunch introduces the emotion word "disgusting" to describe the action of another girl present who was eating without utensils, while the others align with the first girl across the sequence of interaction with embodied displays, such as turning-away of their bodies. The researchers argue that the first girl's embodied "individual display of affective stance is transformed into a shared, multiparty display of stance toward, and disgust with" the talked-about girl (Goodwin, Cekaite and Goodwin 2012: 23).

Embodiment plays an important role in displays of stance. M.H. Goodwin (2007) presents an assessment sequence in which two girls elaborate how they feel regarding an absent team captain, who had excluded them from a game, and his girlfriend. Hand gestures underscore their similar assessments of the non-present peers as silly and reprehensible. Moreover, the timing of the gestures and alignment of the two girls' bodies were crucial to both elaborating the moral order and exclusion of a third girl who was present but not as aligned as the other two in the postural configuration of her body and hand gestures. Also crucial was the girls" use of "format-tied" utterances, i.e., "utterances that make use of parallel structures" (2007: 356; see also M.H. Goodwin 1990). Goodwin concludes that "one of the hallmarks of showing that people's minds 
are together is producing assessments in overlap" and that gesture, the postural arrangement of bodies, the use of parallel linguistic structures and displays of affect, and the sequential analysis of talk are all key in making "visible a local social order of exclusion and inclusion" (2007: 357, 359). This publicly available "ensemble of emotion and stance" can be disassembled and reassembled by participants "to build new forms of action through progressive transformation of [the] prior ensemble" (Goodwin, Cekaite and Goodwin 2012: 23; see also C. Goodwin 2013).

In Goffman's work on "remedial interchanges", participants act to remedy the moral order and maintain their good character. Accounts in remedial interchanges index events that are potentially morally problematic and attempt to recategorize them (Goffman 1971; Sterponi 2009). Like accounts in remedial interchanges, affective statements by a child or a parent can index actions in need of remedy on the part of the child or others with whom the child is interacting, hence contribute to the creation of the moral order and the "elaboration of moral expectations and rules" (Cekaite and Evaldsson this issue). Moreover, as discussed by Goffman, remedial work often gives rise to "recycling" (1971: 192). This prior research raises the possibility that how caregivers and very young children shape and recycle affective expressions over sequences of interaction in multi-party exchanges can be consequential for the moral norms that become negotiated in the daycare setting.

\section{Method}

\subsection{Data and Setting}

The data for this study come from a larger corpus of data consisting of 500 hours of video recordings of children's naturalistic interactions with peers and caretakers collected in two toddler-infant daycare centers in California. The children were aged 12-30 months. The data 
were collected twice a week at these centers over two years. ${ }^{1}$

In the analysis that follows, we focus on situations in which a child is a victim of a peer's untoward action (e.g., a child steps on the sand castle of another child). The context of peer conflicts is a "morally charged" situation in which remedial action (Goffman 1971) can be indicated. An adult intervenes with institutionally sanctioned emotion talk in which the child is encouraged to "use your words" to express their feeling. This institutionally-provided discourse of feeling is part of the RIE curriculum, which encourages the self-confidence and "natural abilities" of young children (see Gerber and Johnson 1998; Gonzalez-Mena and Eyer 2001) and is widely used with young toddlers and preschoolers in child care programs in the United States.

\subsection{Analytical Approach}

Over several years of studying features of conflicts with friends of 7 target children in these data (Köymen 2010; Köymen and Kyratzis 2014; Kyratzis 2009), we had observed that a prevalent linguistic vehicle through which this "use your words" curriculum was implemented by caregivers was in the form complement constructions with verbs of saying or feeling such as “Are you saying, ‘no, don’t stand on me?’” (see Köymen 2010; Köymen and Kyratzis 2014). The child might then tie to the format of the expression used by the caregiver and produce a complement construction with these kinds of verbs her or himself. In the construction below, Devon produces the complement construction "I said 'I don't want him do it"” after being primed by the caregiver's own use of a complement construction and affective expression, "Did you

\footnotetext{
1 The original study went through Human Subjects Committee review to ensure that it followed the University of California, Santa Barbara's ethical principles for the protection of human subjects in research, which follow those set forth in the Belmont Report of the National Commission for the Protection of Human Subjects of Biomedical and Behavioral Research and protections provided in 45 CFR Part 46. Informed consent was obtained from parents of children and center teachers. The authors of the current study agreed to the conditions of use of the corpus.
} 
need to say something?".

1 DEVON; Don't throw.

2 CG; Did you need to say something?

$>3$ DEVON; I said 'I don't want him do it'.

Like accounts in remedial interchanges (Goffman 1971), the child's affective statements with "want" and "say" are targeted by the curriculum because they can make the child's request for stoppage of the peer's infraction clear to the peer, by emphasizing the child's affective response and orientation to the infraction (Sterponi 2009). Fifty-seven complement constructions (and the discourse surrounding them) were identified for a dissertation study of all the complement constructions produced by the 7 target children in this database conducted by the second author (Köymen 2010). In what follows, we report on 3 examples drawn from these complement constructions. We combine a conversation analytic examination of talk-ininteraction with an ethnomethodological concern for how the participants themselves were orienting to the infractions. We focus on how the affective statements are shaped syntactically and multimodally, how they serve as integral parts of the remedial action being constituted, and how they are oriented to the participants in terms of the moral frameworks they make relevant.

\section{Analysis}

\subsection{Adults Providing Institutional Affective Discourses for Children in Peer Disputes}

As this is a daycare center with very young children aged $12-30$ months, adults are never far away. In the examples in this section, when a nearby adult hears a child crying or hitting a peer during a peer dispute, they orient to the crying as a "manifestation of distress" (Cekaite and Holm 2017: 109). When they model an expression of saying and feeling for the upset child to use in the dispute ("Are you saying 'no don't stand on me?"”), the child may, then, "tie" to the format of 
this affective expression. In this way, the child is provided with a resource to index their distress and therefore frame the peer's action as in need of remedy, enabling the peer committing the infraction to become aware of their hurt feeling and stop the action. However, the child may only partially tie to the format of the adult's utterance, "delaminating" (C. Goodwin 2013) and altering the format of the modeled request in a way that shifts the action requested from merely stoppage of the untoward action to an alternative action which may, in turn, infringe on the rights of the originally transgressing peer.

In the first excerpt, ${ }^{2}$ a girl, Sammy, ${ }^{3}$ is being pushed by her peer and is urged to appropriately channel her display of hurt feeling from crying to telling through caregiverprovided affective statements. Sammy ties to the format of her caregiver's phrases and tells her want to her peer, but her display takes an inappropriate turn from upset to aggression as she comes to push her peer away at the same time that she is using her words to tell him what she would like him to do.

EXCERPT 1: Children and ages: Sammy (female, 2;6); Scott (male, 1;8)

1 ((Scott tries to hit Sammy as she lies across couch))

2 ((CG on the other side points towards Scott))

3 CG: Sammy you can tell him to stop.

4 SAMMY: A::h, A::h, A::h, ((crying))

5 CG: $\quad$ Tell him to stop. ((points towards Scott))

6 SAMMY: Sto:p.

7 CG: 'Move away',

$8 \quad$ (.5) And then move away, ((Suggesting Sammy move))

9 SAMMY: Move away,

10 Move away, ((pushes Scott's face on couch pillow))

$11 \quad$ ((Scott moves away))

12 ((Scott puts his face on couch pillow))

${ }^{2}$ See Appendix for Transcription Conventions

${ }^{3}$ All names of children and participants used in this paper are pseudonyms. 
13 ((Scott makes an angelic expression))

14 SAMMY: Move awa:y

Move awa:y, ((pushes Scott's face on pillow))

(.5) Move away.

((Scott doesn't move, CG comes over))

I want him move away. ((looking at CG))

I want him move away. ((whiny voice))

If you don't like what he's doing, You can move away.

In Excerpt 1, both children are at a couch, with Sammy lying on it and Scott sitting on the floor by the couch. The conflict starts because Scott attempts to hit Sammy. Sammy begins to cry (line 4), indexing Scott's action as inappropriate. The caregiver too orients to Scott's behavior as untoward and the caregiver intervenes, modeling a directive for Sammy to use, "stop", and embedding it into a complement construction with a verb of telling, "You can tell him to stop" (lines 3-5). She then models a directive for Sammy to use, "move away" (line 7), although in the next utterance, she directs Sammy herself to also move away, to help make possible the stoppage of the peer's untoward action. Quite different from Cekaite and Holm's (2017) observations, the adult does not legitimize the crying. The caregiver's use of verbs of saying downplays and indirectly questions the child's use of certain affect displays (here crying). Instead, she highlights the need to verbalize affect in terms of the child's needs, thereby transforming inner feelings into actions.

In line 9, Sammy follows up on the caregiver's suggestion. She recycles the adult's "move away" and helps Scott in moving away by pushing at his face on the pillow. He moves his body back although still leaving his head on the pillow. To challenge Sammy's indexing of his move as sanctionable and to highlight Sammy's own now evident commission of an untoward action (i.e., pushing her peer's head off the couch pillow), Scott makes an embodied display of his own, an angelic facial expression projecting his innocence (see line 13). Sammy says "move 
away" and pushes again (line 15). Meanwhile, in response to the escalation of conflict and Sammy's physical act of pushing Scott, the caregiver has come over to the couch. As she arrives, Sammy looks up at her and whines about Scott by saying, "I want him move away" (lines 18 and 19).

Sammy's construction in these lines repeats the recycled directive ("move away") but embeds it into a construction with the verb "want", similar to the stance construction with "tell" that the caregiver had modeled in lines 3 and 5 and says, "I want him move away." By paralleling the caregiver's construction over several turns and looking at her, Sammy is exhibiting that her “mind is together" (M.H. Goodwin 2007) with the caregiver's, inviting her to align with her against her peer. Sammy's plaintive voice, exhibited stance, and use of the institutional affective discourse index a moral order in which Scott's failure to move away is harming her and is therefore unacceptable. However, Sammy's embodied affective displays and the moral order they make relevant is questioned by the caregiver. Sammy has misused the affective discourse to call attention to a different action than that referenced by the caregiver, one which does not merely stop the peer's action of hitting her, but which requests sole access to space on the couch, which Scott has equal right to. Through the format of her construction, she is indexing a moral order in which Scott does not have a right to a space on the couch. Scott, as do other children at the center, has a right to be in the vicinity of the couch. He just does not have the right to hit Sammy. Accordingly, the teacher corrects the moral order that is invoked by Sammy's affective displays to the institution-sanctioned one, by saying in lines 20-21, “if you don't like what he's doing, you can move away."

It is notable how the caregiver's use of defensive expressions, verbs of saying instead of feeling, downplays and indirectly questions the child's use of certain affect displays (here 
crying). Instead, she highlights the need to verbalize affect in terms of the child's needs, thereby transforming inner feelings into actions. It is also notable how the child ties to and exploits the institutional affective discourse and takes advantage of the institutional format, first by crying, but then in a more indirect, adult-guided, and institutionally acceptable way, by verbally expressing her feelings. However, she takes the caregiver's directives and primes in a different direction from that intended by the caregiver. By exhibiting her stance, she attempts to one-up her peer and gain rights over him that she is not entitled to, using the teacher's orientation to conflict resolution for her own purposes. Of interest here is how crying and verbally asking for help can be used to cast the other peer's actions as something negative and in need of being remedied (Goffman 1971), thereby creating advantages for the one who is "using their words".

In the next excerpt, the two children, Sammy and Scott, are engaged in a conflict over Scott's stepping on Sammy's sand castle. Sammy attempts a directive "you're stepping on the castle. Out". This directive is deconstructed and reconstructed, or "delaminated" (C. Goodwin 2013), by the caregiver to a format more in line with the institutional affective discourse. It is then reconstructed and recycled by Sammy to influence the three-way participation structure and achieve her own goals in the interaction.

EXCERPT 2: Children and ages: Scott (male, 2;1), Sammy (female, 2;10)

1 ((Sammy is making a sand castle.))

2 ((Scott steps on the castle.))

3 SAMMY: You're stepping on the castle.

$4 \quad$ Out. ((Pushes Scott))

5 CG: Wo:w,

6 SAMMY: I want him out.

7 ((Scott tries to step on the castle.))

8 SAMMY: No. ((Covering castle with her body))

$9 \quad$ ((Scott steps on her))

10 Aw au:w au::w. ((Sammy cries, bringing over a CG))

11 CG: Sammy are you saying 'no don't stand on me'?

12 SAMMY: No. 
13 Standing on the castle.

14 CG: You know what,

15 I don't know if that castle belongs just to you or not.

16 You (xxx) with everybody.

$17 \quad$ ((Scott stands on the castle.))

18 SAMMY: I don't want him sta:nd on it. ((shouting))

In lines 3-4, Sammy attempts a directive "out", prefacing it by making an accusation in the second person, "You're stepping on the castle". She also pushes Scott away. However, he goes to stand on the castle again. Sammy responds by saying "no" and covering the castle with her body (line 8), putting herself in the path of Scott's act of stepping and thereby making an embodied display of being stepped on. She also makes a crying sound in line 10, "aw, au::w, au::w". These are embodied displays of being harmed by Scott's action, underscoring the type of transgression that caregivers at this center usually orient to as needing remedy, stopping physical acts of aggression.

As Sammy put her body in the trajectory of Scott's action of stepping, Scott actually does step on her lightly. In line 11, a nearby caregiver, probably observing the physical aspects of the dispute (Sammy is now being stepped on by Scott) intervenes in the dispute. The caregiver ties to the format of Sammy's directive but delaminates and reformulates it (C. Goodwin 2013) to a format more in keeping with the school ideology and moral order of acknowledging children's hurt feelings while not limiting other children's rights. She says, "Sammy are you saying 'no don't stand on me'”? Sammy's embodied display of hurt affect (being stepped on and crying) was in keeping with the school ideology of making her hurt feelings known to the misbehaving peer, but her second-person grammatical construction, "You are stepping on the castle", accused her peer and were not respectful of his right to also be able to use material in the sandbox. In response, the caregiver's utterance in line 11 acts to delaminate Sammy's affect display and accompanying utterance into a format which is more in keeping with the school ideology. She 
describes the peer's untoward action as being stepping on her rather than on the castle. As noted by Cekaite and Evaldsson (this issue), "children's affective stances [can] become the target of the moral inspection of an adult authority". Here, through recycling Sammy's directive, the caregiver attempts to correct the child's utterance to a format which indexes a moral order by which physically hurtful acts, rather than bids to share space, are worthy of remedial action.

In lines 12-13, Sammy attempts to take advantage of the institutional format and adultguided way of verbally expressing her feelings, modeled by the caregiver. She does so by repeating the elements "no" and "stand on" from the caregiver's utterance: "No standing on the castle". Unlike the caregiver, however, and in keeping with her own earlier more accusing utterance, in line 3 ("you're stepping on the castle"), she says "on the castle" rather than "on me" which the caregiver had primed her to say. Sammy is misusing the affective discourse to call attention to a different action than that referenced by the caregiver, one which does not merely stop the peer's untoward action of stepping on her (and causing her distress), but which requests that Scott move away from the castle in the sandbox, an object which Scott has equal right to.

In line 15, the caregiver expresses her disapproval of Sammy's words “no standing on the castle", indicating that "I don't know if the castle belongs just to you or not." The child's affective stances have again become the target of adult scrutiny. In line 18, Sammy turns to face the caregiver. She recycles her "standing on the castle" by delaminating and embedding it into a complement construction with a verb of intention ("I don't want") in front of it, stating loudly "I don't want him stand on it". The stance-expression ("I don't want") resonates with the caregiver's earlier use of a verb of telling ("Sammy are you saying..."). Although the verb of intention that Sammy uses, "want", is a different verb than the one the caregiver had used, her tying to the format of the adult caregiver's construction lends an adult-sanctioned quality to 
Sammy's stance expression. By expressing her stance through recycling the caregiver's utterances, Sammy invites the caregiver to take a congruent stance to her own on the sequence of action (M.H. Goodwin 2007). Although she uses her words in keeping with the school's remedial practice, she also subverts the affective discourses and the moral order they invoke (e.g., children should not physically harm other children) by making relevant an alternative moral order which limits her peer's rights to the castle and sandbox. The adult caregiver, in turn, designs her feedback to correct this moral order invoked by Sammy.

It is notable in Excerpt 2 how the adult, rather than legitimizing the crying (Cekaite and Holm 2017), prompts the child to control her distress and transform it into (verbal) action. It is also notable how the caregiver responds to Sammy's embodied display of being harmed as she lies across the castle enabling Scott to step on her. The caregiver models defensive expressions that are "delaminated" (C. Goodwin 2013) from the format of the expressions which the child uses and which make relevant a different moral order (one in which children have a right to not be physically harmed by other children) than the one invoked by the child (i.e., one in which Scott does not have a right to be in the sandbox). It is also notable how the child exploits the institutional affective discourse and takes advantage of the institutional format, first by crying (line 10) and through embodiment (by lying across the castle so that her peer is able to step on her), but then in the more indirect, adult-guided, and institutionally acceptable way, by verbally expressing her feelings, modeled by the caregiver. Sammy, as encouraged, exhibits her affective stances in order to carry out the moral work of framing the peer's actions as something negative and in need of being remedied (Goffman 1971), thereby creating advantages for the one who is "using their words". 
Finally, it is also notable how the utterances of both speakers become taken up and tied to in the interaction (M.H. Goodwin 1990), and how the long complement construction ultimately produced by Sammy at the end of the episode ("I don't want him sta:nd on it") is emergent and built up gradually over turns through her using the elements provided by the talk in prior turns. In being provided with the complement construction format by the adult in line 11, which she subsequently delaminates and selectively reuses, Sammy is afforded a grammatical resource for revisiting her original directive ("no standing on the castle"), noting her affective position and stance on its not having been complied with ('I don't want him stand on it), and for exhibiting congruence with the position taken by another participant in the interaction, that of the caregiver (M.H. Goodwin 2006, 2007). For these young speakers, the meaningfulness of their utterances is "not 'encoded' in [their] talk alone. Instead the production of meaning and action draws upon resources provided by the sequential organization of the unfolding conversation" (C. Goodwin, M.H. Goodwin and Olsher 2002: 31).

\subsection{Children Initiating (and Subverting) Affective Discourses during Peer Disputes}

Although normative affective discourses are provided to children in childcare centers adopting the RIE curriculum, children may not necessarily take them up as presented. Children do not merely appropriate adults' rules (Martin and Evaldsson 2012). Children's agency can be seen even more clearly in cases where they initiate the institutionally provided affective discourses.

Excerpt 3 shows Scott initiating the use of the institutionally-provided formulaic expressions "I do not like it" and "I said "don't do it"” and taking them too far, using them to shout and exhibit anger toward his peer when that peer calls his name out loud several times. By 
shouting at his peer, Scott subverts the institutional, cultural remedial practice and the impetus for peer-to-peer understanding.

EXCERPT 3a: Children and ages: Scott $(2 ; 3)$, Roger $(2 ; 5)$

$1 \quad(($ Scott and Roger are at the breakfast table $))$

2 ROGER: Sco::tt,

$3 \quad$ Scott $\underline{S c o: t t} \underline{S c o: t t}$,

$4 \quad$ Scott ((says it tentatively, slowly))

5 SCOTT: STOP IT SCOTT (XXXXXX) (MY NAME).

6 ROGER: But I said 'Scott is',

7 SCOTT: No. I do not like it,

8 I do not like it mommy,

9 S's MOM: What don't you like.

10 SCOTT: I do not like it he say 'Scott'.

11 S's MOM: You don't like what.

12 SCOTT: When he say 'Scott'.

13 S's MOM: When Roger says 'Scott'?

14 SCOTT: Yeah.

15 S's MOM: He's just being friendly.

Excerpt 3a begins when Roger tries to get his friend Scott's attention from the next table by calling his name tentatively in lines 2-4. Hearing this, Scott begins shouting at Roger and uses an imperative by saying, "stop it". In line 6, Roger embeds his own prior utterance by prefacing it with a verb of saying to defend his position, "But I said 'Scott is"'. In line 7, Scott complains about Roger's words by saying, "I do not like it". Here, Scott exploits the institutional affective discourse. He speaks in the indirect, adult-guided, and institutionally acceptable way, by verbally expressing his feelings, using the institutionally provided phrases with "I don't like it" to index his peer's action as unacceptable.

Scott then expands the participation framework by amending a vocative to his statement, "I do not like it mommy" (line 8) and invites his mom (who is visiting the daycare) to join the participation framework, and solicits her alignment with him against Roger. When his mom asks him what he does not like (in line 9), Scott uses her question as a prompt to elaborate his 
assessment of the event. He formulates a complement construction "I do not like it (when) he say 'Scott'” (lines 10-12) by recycling syntactic fragments of what Roger said in line 6 ("But I said 'Scott is"'), and embedding them into his earlier complaint ("I do not like it", lines 7-8). Through this complement construction "I do not like it (when) he say 'Scott", Scott reports what Roger said and takes a stance on Roger's words "I do not like it he say 'Scott". By reporting the speech of Roger and his own stance on it, Scott tries to elicit a similar assessment from his audience, namely his mom. However, Scott's mom does not align with his projection of his peer Roger's behavior as sanctionable, and in fact aligns with Roger by saying, "He's just being friendly" (line $15)$.

In the second part of the excerpt, the dispute continues as Scott persists in his invocation of the institutional discourse, saying "I said 'no", "I said 'don't do it", to resume carrying out the moral work of framing his peer's action as inappropriate. The peer, Roger, takes advantage of the institutional affective discourse, telling Scott that he does not like it when Scott shouts and that this hurts his ears. A caregiver at the daycare center intervenes in the dispute.

EXCERPT 3b: Children and ages: Scott $(2 ; 3)$, Roger $(2 ; 5)$

16 SCOTT: No,

17 ROGER: Don't scream at me,

18 SCOTT: I SAID - I SAI:D - I SAID 'NO'.

19 CG: $\quad$ Scott $\operatorname{Scott}(\mathrm{xx})$ -

20 Roger was asking you not to scream at him.

21 SCOTT: No,

22 CG: But he heard you.

23 SCOTT: [No. I said 'no'.]

24 CG: [He just doesn't want you to scream at him.]

25 SCOTT: I said no.

26 CG: Okay.

27 ROGER: I don't like this

28 When you shout loud from my ears. ((Covering his ears))

29 SCOTT: I said 'don't do it'.

30 I said 'don't do it'. Don't do it

31 ROGER: Then don't do you -. 
32 SCOTT: No I said 'do:n't do it' mommy,

33 I said 'don't do it'.

34 CG: Well look at Roger's covering his ears

35 'cause it was loud.

36 SCOTT: I (said) uhm -

37 I (said) 'I do not like it'. ((directed to his Mom))

38 I do::n’t like it.

In line 16, the conflict from Excerpt 3a continues with Scott shouting "No," firmly rejecting his peer Roger's action of saying his name. In line 17, Roger begins to invoke the institutional affective discourse himself, using his words to ask Scott not to scream at him (“don't scream at me”), to which Scott replies by shouting "I SAID - I SAI:D - I SAID 'NO”'. Scott here exploits the institutional affective discourse in the indirect, adult-guided, and institutionally acceptable way, by verbally expressing his feelings and "topicalizing" (Evaldsson and Sahlström 2014) his act of "saying" ("I said").

Scott's shouting brings the caregiver, who intervenes in the conflict in line 20, saying, "Roger is asking you not to scream at him." Here she is invoking the institutional remedial discourse, which requires that children's words and acts of saying be respected. Moreover, to Scott's continued loud "no's" (lines 21, 23) in response to having Roger say his name, the caregiver says "but he heard you" (line 22) and "he just doesn't want you to scream at him" (line 24). Scott's display of affect thus becomes the target of moral inspection and he receives corrective feedback from the adult, both for his loud volume and for his persistence in attempting to stop an action whose harmful affect on him is called into question (i.e., the caregiver points out that the peer Roger "just" does "not want you to scream at him").

When Scott continues the affective discourse by saying "I said "no"" (line 25), the caregiver capitulates ("okay") in line 26. However, the peer, Roger, again takes advantage of the institutional affective discourse, telling Scott (lines 27-28) that he does not like it when Scott 
shouts loudly, using Scott's own format ("I don't like) to topicalize his affective response to Scott's loud statements, and noting the harm they are doing to his ears ("I don't like this when you shout loud from my ears"). He also makes an embodied display of the harm and hurt feeling by covering his ears. When Scott continues making his assertive statements ("I said 'don't do it'", "I said 'don't do it") in lines 29 and 30, and in 32 and 33, this leads the caregiver to again intervene, saying "Well look at Roger's covering his ears 'cause it was loud" (lines 34-35). The caregiver here is underscoring the peer's display of hurt affect and using it to downplay and indirectly question that of the speaker's. She appears to side with the peer, Roger, in the dispute. The peer's embodied display of hurt feeling has been successful in indexing Scott's loud action as inappropriate and garnering the alignment of the caregiver. Even though Scott in lines 34-36 persists in his loud, assertive statements, and recyclings of his affective expressions ("I said I do not like it"), his display of affect and the moral order that he attempts to invoke with it have been challenged by the caregiver.

It is notable in Excerpts 3a and $3 b$ how Scott exploits the institutional affective discourse in the indirect, adult-guided, and institutionally acceptable way, by verbally expressing his feelings, using the institutionally provided phrases with "I don't like X" and phrases with verbs of saying (e.g., "I say Y"), to index his peer Roger's behavior as unacceptable. However, the moral order that he makes relevant with his affective discourse, one in which saying a child's name is inappropriate, is not one that is in place at the daycare center, and so can be seen to represent a subversion on the part of the child, one that he uses to position himself in the local interaction with his friend. The example underscores how children can "negotiate, object and/or even subvert, rather than comply with the expected moral order (Cekaite and Evaldsson this 
issue)." But just as children can use their affective stances to index a particular moral order, these displays can be inspected by the caregivers and corrected.

In Excerpt 3b, Roger, also exploits the institutional affective discourse in the indirect, adult-guided, and institutionally acceptable way, by verbally expressing his feelings ("Don't scream at me"; "I don't like it when you shout loud from my ears."), but not as loudly or repetitively as the other child. Moreover, he accompanies his affective display of using his words with an embodied display of covering his ears to publicly exhibit the harm that he is experiencing from the (loud) action of the other child. Roger's affective displays are more in line with the institutional moral order and therefore more effective than Scott's in "publicly demonstrating his understanding [and felt harm] of the moral transgression" (Cekaite and Evaldsson this issue). Accordingly, they are more effective in eliciting alignment from the caregiver, as seen in her statements sanctioning Scott (e.g. "Well look at Roger's covering his ears 'cause it was loud").

\section{Conclusions}

The moral character of the work done by affect, and its role in providing "information ... to better understand and respond to uncertain information" (Ochs and Schieffelin 1989:21), in particular, what constitutes action in need of being remedied (Goffman 1971), can be seen in the above examples (Goodwin et al. 2012; Cekaite and Evaldsson this issue). The caregivers' uses of defensive expressions, verbs of saying instead of feeling, downplay and indirectly question the children's use of certain affect displays (e.g., crying, shouting). Instead, they highlight the need to verbalize affect in terms of the child's needs, thereby transforming inner feelings into actions. The children exploit the institutional affective discourse socialized at the childcare center, by crying and shouting, but also in the more indirect, adult-guided, and institutionally acceptable 
way, by verbally expressing their feelings. As encouraged, the children exhibit their affective stances in order to carry out the moral work of framing the peer's actions as unacceptable. In this way, the children adopt the caregivers' orientation to conflict resolution. Of interest here is how crying, but more appropriately asking, for help can be used to cast the other peer's actions as something negative and in need of being remedied (Goffman 1971), thereby creating advantages for the one who is "using their words".

The children take up the more indirect, adult-guided, and institutionally acceptable way of verbally expressing their feelings. The children do not only appropriate these institutional affective discourses (Martin and Evaldsson 2012), but also use the teacher's orientation to conflict resolution for their own purposes, making use of institutional affective discourse for exploiting the very same rules. They manipulate displays of hurt feeling to negotiate their own local peer social order (M.H. Goodwin and Kyratzis 2011, 2014; Martin and Evaldsson 2012), thereby subverting rather than exploiting the cultural impetus for peer-to-peer understanding. The teachers recycle this discourse in such a way that the verbal expression of feelings does not become too aggravated and infringe on the peer's rights. In other words, they delaminate and reshape the children's utterances towards invoking the institutional moral order, by which the children have the right not to experience physical harm from their peers, but by which they do not have the right to deny the peer's access to goods and space at the preschool. In addition, the children and the caregivers attend closely to both the verbal and embodied aspects of these performances, underscoring the performative and carefully designed nature of these affect displays.

Indeed, the examples illustrate how quite specific "interactional templates" are provided to children, which can "inculcate the socioculturally sensitive norms and expectations related to 
the shaping of affective relations" (Cekaite and Holm 2017: 125). These are configured with targeted displays of appropriate affect (words, topicalizations) and (in)appropriate affect (crying, shouting). These displays laminate different kinds of modalities and resources, including arrangements of the body (covering of the ears, putting one's body in the proximity of stamping feet), appropriate voice quality and volume (e.g., not too loud), all coordinated with particular syntactic formats of talk (C. Goodwin 2013). Overall, the recycled affective utterances help uncover usually unarticulated normative socio-cultural assumptions underlying the moral order of these U.S. daycares (see also Burdelski 2010; Cekaite 2013), demonstrating how affective work in remedial interchanges serves as "a vantage point from which participants articulate moral values and notions of personhood" (Cekaite and Evaldsson this issue). The examples also illustrate the agency of very young children with quite limited verbal resources in responding to and challenging these articulations. 


\section{Appendix: Transcription symbols}

\begin{tabular}{|c|c|c|}
\hline & Left square bracket & The beginning of overlapping talk \\
\hline & Right square bracket & The end of overlapping talk \\
\hline & Period & Falling intonation \\
\hline & Question mark & Rising intonation \\
\hline & Comma & Continuing intonation \\
\hline & Dash & Abrupt cut-off \\
\hline . & Equal sign & Talk produced without transition-space \\
\hline & Column & Prolonged sound. \\
\hline warm & Underlining & Prominent syllable \\
\hline YOU'LL & All caps & Loud speech \\
\hline & Degree sign & Quiet speech \\
\hline ( ) & Parentheses & Undecipherable speech. \\
\hline (x) & Parentheses w/x's & Undecipherable speech, $x=1$ syllable \\
\hline (warm) & Parentheses around words & Uncertain transcription \\
\hline$\{[\mathrm{ac}]\}$ & "ac" in brackets & Accelerated speech \\
\hline$(0.5)$ & Number in parentheses & Pause of designated no. seconds \\
\hline & Upwards arrow & Heightened pitch \\
\hline$(($ smiling $))$ & Double parentheses & Transcriber's comments \\
\hline
\end{tabular}




\section{References}

Burdelski, Matthew. 2010. Socializing politeness routines: Action, other-orientation, and embodiment in a Japanese preschool. Journal of Pragmatics 42(6). 1606-1621.

Cekaite, Asta. 2013. Socializing emotionally and morally appropriate peer group conduct through classroom discourse. Linguistics and Education 24. 511-522.

Cekaite, Asta \& Ann-Carita Evaldsson. 2008. Staging linguistic identities and negotiating monolingual norms in multiethnic school settings. International Journal of Multilingualism 5. 177-196.

Cekaite, Asta \& Malva Kvist Holm. 2017. The comforting touch: Tactile intimacy and talk in managing children's distress. Research on Language and Social Interaction 50(2). 109127.

Clancy, Patricia. 1986. The acquisition of communicative style in Japanese. In Bambi Schieffelin \& Elinor Ochs (eds.), Language socialization across cultures, 213-50. New York: Cambridge University Press.

Cook-Gumperz, Jenny \& Amy Kyratzis. 2001. Child discourse. In Deborah Schiffrin, Deborah Tannen \& Heidi Hamilton (eds.), A handbook of discourse analysis, 590-611. Oxford: Basil Blackwell.

Evaldsson, Ann-Carita \& Fritz Sahlström. 2014. Metasociolinguistic stance taking and the appropriation of bilingual identities in everyday peer language practices. In Asta Cekaite, Shoshana Blum-Kulka, Vibeke Grøver \& Eva Teubal (eds.), Children's peer talk: Learning from each other, 149-168. Cambridge: Cambridge University Press. 
Evaldsson, Ann-Carita \& Johanna Svahn. 2017. Staging social aggression: Affective stances and moral character work in girls' gossip telling. Research on Children and Social Interaction 1(1). $77-104$.

Gerber, Magda \& Allison Johnson. 1998. Your self-confident baby: How to encourage your child's natural abilities - from the very start. New York: John Wiley \& Sons.

Goffman, Erving. 1971. Relations in public. New York: Basic Books.

Goffman, Erving. 1981. Footing. In Erving Goffman, Forms of talk, 124-159. Philadelphia: University of Pennsylvania Press.

Gonzalez-Mena, Janet \& Dianne W. Eyer. 2001. Infants, toddlers, and caregivers: A curriculum of respectful, responsive care and education, 6th edition. Boston: McGraw-Hill.

Goodwin, Charles. 2013. The co-operative, transformative organization of human action and knowledge. Journal of Pragmatics 46. 8-23.

Goodwin, Charles, Goodwin, Marjorie H. \& David Olsher. 2002. Producing sense with nonsense syllables: Turn and sequence in the conversations of a man with severe aphasia. In Barbara Fox, Cecilia Ford, and Sandra Thompson (eds.), The language of turn and sequence, 56-80. Oxford: Oxford University Press.

Goodwin, Marjorie H. (1990). He-said-she-said: Talk as social organization among black children. Bloomington, IN: Indiana University Press.

Goodwin, Marjorie H. (2006). The hidden life of girls: Games of stance, status, and exclusion. Oxford: Blackwell.

Goodwin, Marjorie H. (2007). Participation and embodied action in preadolescent girls' assessment activity. Research on Language and Social Interaction 40(4). 353-375. 
Goodwin, Marjorie H., Asta Cekaite, \& Charles Goodwin. 2012. Emotion as stance. In Anssi Peräkylä \& Marja Leena Sorjonen (eds.), Emotion in interaction, 16-63. Oxford: Oxford University Press.

Goodwin, Marjorie H. \& Amy Kyratzis. 2011. Peer language socialization. In Alessandro Duranti, Elinor Ochs \& Bambi Schieffelin (eds.), The handbook of language socialization, 391-419. Oxford: Blackwell.

Goodwin, Marjorie H. and Amy Kyratzis. 2014. Language and gender in peer interactions among children and youth. In Miriam Meyerhoff and Susan Ehrlich (eds.), The Handbook of language, gender, and sexuality, 509-528. Oxford: Wiley-Blackwell.

Johnson, Sarah J. 2017. Multimodality and footing in peer correction in reading picture books. Linguistics and Education 41. 20-34.

Kemp, Jacqueline L. \&Amy Kyratzis. 2018. Moral order among a friendship group of preschool boys. Research on Children and Social Interaction 2(2). 235-261.

Kidwell, Mardi. 2005. Gaze as social control: How very young children differentiate "The Look" from a "Mere Look" by their adult caregivers. Research on Language and Social Interaction 38(4). 417-449.

Köymen, Bahar. 2010. "I said 'I don't want him do it'”: Toddlers' usage of complement constructions within interactions in daycare. Unpublished Doctoral Dissertation, University of California, Santa Barbara.

Köymen, Bahar \& Amy Kyratzis. 2014. Dialogic syntax and complement constructions in toddlers' peer interactions. Cognitive Linguistics 25(3). 497-521.

Kyratzis, Amy. 2001. Emotion talk in preschool same-sex friendship groups: Fluidity over time and context. [Special issue]. Early Education and Development 12.359-391. 
Kyratzis, Amy. 2009. "He take one of my tools!" vs. "I'm building": Transitivity and the grammar of accusing, commanding, and perspective-sharing in toddler's peer disputes. In Jiansheng Guo, Elena Lieven, Nancy Budwig, Susan M. Ervin-Tripp, Keiko Nakamura \& Seyda Özçaliskan (Eds.), Crosslinguistic approaches to the study of language: Research in the tradition of Dan Isaac Slobin, 41-54. Mahwah, NJ: Erlbaum.

Kyratzis, Amy. 2017. Peer ecologies for learning how to read: Exhibiting reading, orchestrating participation, and learning over time in bilingual Mexican-American preschoolers' play enactments of reading to a peer. Linguistics and Education 41. 7-19.

Martin, Cathrin \& Ann-Carita Evaldsson. 2012. Affordances for participation: Children's appropriation of rules in a Reggio Emilia School. Mind, Culture, and Activity 19. 51-74. Ochs, Elinor \& Bambi Schieffelin. 1989. Language has a heart. Text 9(1). 7-25.

Ochs, Elinor \& Bambi Schieffelin. 2011. The theory of language socialization. In Alessandro Duranti, Elinor Ochs \& Bambi Schieffelin (eds.), The handbook of language socialization, 1-22. Oxford: Blackwell.

Sterponi, Laura. 2009. Accountability in family discourse: Socialization into norms and standards and negotiation of responsibility in Italian dinner conversations. Childhood 16(4). 441459.

Tarım, Seyda Deniz \& Amy Kyratzis. 2012. Challenging and orienting to monolingual school norms in Turkish American children's peer disputes and classroom negotiations at a U.S. Turkish Saturday school. In Susan Danby \& Maryanne Theobald (eds.), Disputes in everyday life: Social and moral orders of children and young people (Sociological Studies of Children and Youth, Volume 15), 193-220. Bingley, West Yorkshire, UK: Emerald Group Publishing Limited. 